Valentyna KUDRYAVTSEVA, orcid.org/0000-0003-4264-4229

Candidate of Pedagogical Sciences, Associate Professor, Head of English Language Department for Deck Officers

Kherson State Maritime Academy (Kherson,Ukraine)florakv07@gmail.com

Svitlana BARSUK, orcid.org/0000-0002-5487-8690 Candidate of Pedagogical Sciences, Assistant Professor at the English Language Department for Deck Officers Kherson State Maritime Academy (Kherson,Ukraine) badger.svetlana@gmail.com

\title{
ORGANIZING PERSONALIZED INSTRUCTION FOR STUDENTS OF MARITIME ENGLISH
}

The article describes the practice of implementing personalized instruction into the educational process to teach English for future deck officers.

There is no universally adopted structure of personalized teaching, as it depends on the nature of training course, its goals and individual students' peculiarities. The article defines a set of core elements essential for this approach which can be universal as well as specific for a certain training course.

The basic elements of personalized instruction, that can be of efficient use in teaching Maritime English, have been chosen to characterize in the article. Flexible content and digital tools, data analysis, targeted instruction, and playlists are presented as the core elements used by the authors in their everyday practice. The authors focus on selecting proper learning materials, tailoring them to students' personal needs, creating playlists and usage of digital educational platforms to make the regular data analysis and targeted instructions for different groups of students based on their interests, learning styles, individual learning pace, and language skills levels.

As a result of personalized instruction implementation students' involvement has improved significantly; they are actively engaged in classroom practice and, that is typical for this approach, beyond the class. Constant self-reflection and teacher's feedback on student progress lead to thorough understanding of an individual's learning style, and provide students with the strategies they use to succeed. Students demonstrate readiness to take responsibility for their individual progress, collaborate and inquire to perform flipped classroom activities. To measure efficiency of embedding personalized instruction on day-to-day basis, teachers assess students' language performance, degree of their learning practice involvement, level of developing their soft skills (decision making, teamwork, effective communication); and the results are introduced in a descriptive way along the article's body.

The authors concluded that efficiency and perspective of personalized instruction mainly depend on the teachers' initiative and students 'maturity to take responsibility for their learning.

Key words: data analysis, digital tools, flexible content, personalized instruction, playlists, targeted instruction.

Валентина КУДРЯВЦЕВА, orcid.org/0000-0003-4264-4229 кандидат педагогічних наук, доиент, завідувач кафедри англійської мови в судноводінні Херсонської державної морської академії (Херсон, Україна)florakv07@gmail.com

Світлана БАРСУК, orcid.org/0000-0002-5487-8690 кандидат педагогічних наук, дочент кафедри англійської мови в судноводінні

Херсонської державної морської академії (Херсон, Украӥна) badger.svetlana@gmail.com 


\section{ОРГАНІЗАЦІЯ ПЕРСОНАЛІЗОВАНОГО НАВЧАННЯ СТУДЕНТІВ МОРСЬКИХ СПЕЦІАЛЬНОСТЕЙ}

У статті йдеться мова про практику застосування персоналізованого навчання в освітньому процесі 3 оволодіння англійською мовою майбутніми палубними офіцерами.

Персоналізоване навчання не може мати універсально визнаної структури, оскільки остання залежить від сутності навчального предмета, його ичілей та індивідуальних особливостей студентів. Описується набір основних елементів, які є суттєвими для цฺього підходу й можуть бути як універсальними, так $і$ специифічними для певного навчального курсу.

Характеризуються базові елементи персоналізованого навчання, які обрані на підставі своєї ефективності у викладанні морської англійської мови. У повсякденній практиці авторами використовувалися й тому вибрані для представлення такі елементи, як гнучкий зміст, ичифрові інструменти, аналіз даних, цілеспрямоване навчання та плейлисти. Автори зосереджують увагу на необхідності відбору належних навчальних матеріалів, їх приладження до персональних потреб студентів, розробиі плейлистів і використанні циифрових навчальних платформ для уможливлення регулярного аналізу даних і иілеспрямованого навчання різних груп студентів на основі їхніх інтересів, стилів навчання, індивідуального темпу навчання й рівня мовних умінь.

У результаті застосування персоналізованого навчання значно зросло залучення студентів до навчального процесу; вони активнімі у виконанні завдань під час начальних занять $i$, щзо типово для цьього підходу, поза ними в самостійній роботі з підготовки до занять. Звичка до саморефлексї й підтримуючі коментарі викладача стосовно мовних досягнень студента ведуть до усвідомлення власного стилю навчання, а також забезпечують студентів стратегіями, які допомагають їм успішно навчатися. Студенти демонструють готовність брати на себе відповідальність за власний успіх у навчанні, співпраџювати й розпитувати при виконанні завдань у режимі «перевернутий клас». Для визначення ефективності запровадження персоналізованого навчання на щзоденній основі викладачі оцінюють володіння студентами мовою, рівень їхнього залучення до навчальної практики, рівень розвитку їхніх м'яких умінь (прийняття рішень, командна робота, ефективне спілкування); а результати представлені в описовому вигляді упродовж статті.

Автори доходять висновку, що ефективність і перспективність персоналізованого навчання переважно залежить від власної ініціативності викладачів і готовності студентів узяти відповідальність за своє навчання.

Ключові слова: аналіз даних, цифрові інструменти, гнучкий зміст, персоналізоване навчання, плейлисти, цілеспрямоване навчання.

Problem statement. Researchers in the field of teaching methodology use various terms when focusing on ways of instruction, taking consideration of students' cognitive and psychological peculiarities, their life experience, and background knowledge. Those terms for such teaching are individualized instruction, differentiated instruction, and, most recently, personalized instruction, personalization. All of them have slight inconsistencies, if any. To that, the words "teaching" and "learning" are often used together or interchangeably, without distinguishing between them. In this article, we have chosen to investigate what basic elements of personalized instruction can be of efficient use in teaching Maritime English.

Researches analyses. Definitions of personalized instruction as well as ideas on basic elements of personalized instruction are numerous, ranging from a few to many or determined vaguely.

An American researcher Vargo J. presents an expansive view of personalized approach that "always involves these core four elements - targeted instruction, data-driven decisions, flexible content, and student reflection and ownership", further adding self-reflection, goal-setting, flexible and intentional schedules, digital content and tools, personalized playlists, flexible seating, and grading conversations (Vargo, 2017: 4).
Another vision of personalized instruction includes the following elements: a tailor-made education program, a strong teacher-student bond, group instruction, project-based learning, overhauling the learning space, use of technology, online learning, and remote experts. As we see it, both lists of personalized instruction components are too wide and too divergent for practical implementation at a training institution (Kim, 2019).

A list of vague descriptions of personalized instruction elements which needs further clarification includes: a design focused on patterns of student needs, a response to learner variance, a versatile approach to instruction that can take many forms, a student-focused way of looking at teaching and learning, a balance between the needs of teacher and student, a desire to give every student a chance to succeed (Watanabe-Crockett, 2017).

No more distinct seems another model of eight personalized instruction elements: formative assessment, goal setting and tracking, quality teaching, curriculum, student grouping, supporting student needs, intervention, and environment (Bautista, Romiro, 2012). The researchers use the term "independent variables" instead of components. The term can be understood by comparing it with another term - "dependent variable" which is student aca- 
demic achievement. Thus, independent means not connected with the students' level of knowledge in a specific discipline. In the author's opinion, the components/variables of personalized instruction are constructivist environment, cooperative learning arrangement, small group discussion, active learning, flexible scheduling and pacing, checkpoint, and authentic assessment. The final conclusion states: "...personalized instruction is an effective mechanism of increasing classroom efficiency" (Bautista, Romiro, 2012: 579).

Analyzing the relevance between such components of personalized instruction as contextual grounding (descriptions of or engagement in everyday situations), funds of knowledge (resources that students bring with them to school from engaging in and observing activity in their home and community), and cognitive load and transfer (demands that learners face due to characteristics of different tasks as they interact with the strengths and limitations inherent in their cognitive architecture), the researchers Walkington and Bernacki conclude that "a critical component of relevance lies within the cognitive domain - instruction becomes relevant when it connects to learners' prior knowledge and experience" (Walkington, Bernacki, 2017: 33).

Keefe and Jenkins propose six basic elements of personalized instruction which they think are "constituting the culture and context of personalized instruction": a dual teacher role, diagnosis of relevant student learning characteristics, culture of collegiality, interactive learning environment, flexible scheduling, and authentic assessment (Keefe, Jenkins, 2000: 40). The first three components are cultural which are thought to establish the foundation of personalization; the last three are contextual components which can promote and support student engagement and proficient performance. The authors stress, "Instruction is personalized when it a) focuses specifically on the needs, talents, learning style, interests, and academic background of each learner, and b) when it challenges each learner to grow and advance from where he or she is at a given point in time to a point beyond" (Keefe, Jenkins, 2000: 97).

In another approach, where the necessity of the instruction co-designed by teachers and learners is emphasized, three important components of personalized co-instruction are considered to be: a) detailed maps that link learning goals to standards, specify the skills and knowledge necessary to meet learning goals, and show hierarchical relationships among goals; b) continuous formative assessment that involves the learner in a proactive manner; and c) a systematic, explicit focus on developing self- regulated learning skills, with learners gradually taking on more responsibility in determining what they need to learn, how they can go about learning it, and measuring their own skill mastery to determine whether their chosen method is working for them (Sota, 2016: 59).

Clear as this may be, the ideas for personalized instruction vary greatly. Some researchers present general institutional approaches to personalized instruction, while others focus on practical teaching steps. The basic idea here is in understanding differences between training institutions, disciplines taught, teachers' possibilities of knowing the students' content background, their cognitive abilities and using this knowledge to organize efficient learning outcomes. Though each episode in personalized instruction seems to be unique, it should be grounded on a set of components for a certain discipline approved by the faculty and recognized by the teachers.

With personalized instruction implemented, students are in the centre of teaching and learning processes. The Model Course, designed by International Maritime Organization for maritime training institutions, stipulates that the student-centered, reflective approach to teaching Maritime English is a must. "... based on the instructor understanding and responding to a trainee's needs which means that s/he must take an interest in the group as individuals", this approach generates personalized instruction (IMO Model Course 3.17, 2015: 208).

The purpose of the article is to specify possible components of personalized instruction for efficient acquisition of Maritime English and provide guidelines on embedding personalized instruction into a classroom practice.

Discussion. The process of personalized instruction construction usually starts with a competencybased approach implication to develop a studentfocused curriculum and meet the needs to train profession-oriented skills at higher education institutions. To train future seafarers, Maritime English teachers use the industry standards and requirements, such as STCW Convention and IMO Model Course to determine professional communicative competencies, embed them into the syllabus, and develop course books which are an essential part of a teaching content.

The curriculum customizing and instruction flexibility are aimed to meet students' needs and interests and create a personalized learning environment to make a link between an individual student and the studying process (Slocum, 2016). To achieve this goal, it is necessary to develop a flexible learning materials bank and variable tools to adjust the path, 
pace, and types of students' performance to their preferences.

According to the degree of flexibility the learning content can be differentiated into three types: foundational content, adaptive and highly customizable content and tools (Johns, Wolking, 2015). To develop professional competencies and train communication skills, future seafarers are offered a wide range of professional contexts. Following the course syllabus, students explore different IMO publications, such as international conventions, reports, checklists, telexes, maritime business correspondence as foundational content that presents a "backbone" of the course. Such texts may appear to be above the students' language level, and the pace of students' engagement can vary. To keep them authentic and meet educational standards, the teacher's task is to facilitate the learning process and scaffold reading comprehension by creating vocabulary practice exercises (match terms with their meaning, give definitions, replace new vocabulary by synonyms, fill in the gaps, etc.) and to train the targeted skills (complete the statements, prioritize, justify your decision, etc.).

Alternatively, the articles on different professional websites used as a part of learning content can be simplified or adapted (summarized, paraphrased or shortened) to ensure that the content itself is at students' achievable level. Although it may result in the loss of authenticity, such adaptive content can still be a useful source of information, and teacher has more flexibility to differentiate performance tasks and provide a variety of learning pathways to students, on both online and offline courses.

The highest degree of flexibility is provided by the content based on the students' personal experience. One of the distinguishing features of maritime education is implementing "learning by doing" method and integrating a sea-going experience into the learning process. It means students themselves are a valuable source of information to transfer into a learning content. This is the case when teacher should encourage students to share their experience and use it as a highly customized input to introduce the subject matter and language mastering.

One more way to tailor the content is differentiating performance tasks at the production stage of a lesson. A well-organized task provides an opportunity to apply professional and language knowledge in an authentic way. Students can work individually or in small groups to collaborate, investigate and finally make a presentation to introduce their findings or to role play a situation and simulate a profession-oriented communication; they can also discuss a case and suggest possible ways to solve the problem. A proper choice of a final performance task is critical, as it is focused on demonstration of lesson's outcomes and reflects individual students' needs and progress.

Next step to organize personalized instruction is selecting proper methods to be applied from a wide spectrum of pedagogical approaches. One of them is flipped classrooms, when students first explore new learning materias at home (often online) and then discuss and apply new knowledge in a variety of ways in class. Such approach is recognized widely applicable in maritime institutions as future seafarers are highly motivated to have quick career growth; they have already identified their interests, and teacher's task is to support them with a set of learning strategies to use for self-studying (Kudryavtseva, 2019).

For example, within the topic Conduct of Vessels in Sight of One Another, the students are assigned to study the corresponding COLREG rules at home. Students are free in exploring different resources (COLREG itself, online videos or articles websites), and applying various strategies, among which are using dictionaries (monolingual or bilingual), guessing the meaning from the context, searching for synonyms or paraphrasing. Flipped classrooms, besides developing self-study skills, enable students to reflect on their learning style by differentiating a path and devoting unlimited time to perform the task. As a result, students scrutinize the learning content beyond the class, and at the lessons they use time in the most beneficial way to practise language in a communicative interaction. The types of performance tasks to apply new knowledge and train language skills can vary from a semi-controlled and guided practice to a free production and engage students into language mastering in a meaningful way by collaborating and demonstrating their professional communication skills.

One more approach used to organize personalized instruction is inquiry-based learning, when students are engaged in an investigation process generated by teacher's question (structured/guided inquiry) or initiated by themselves (free inquiry), and investigate various resources to search for the answers. This approach makes it possible for students to trace their own learning path and achieve the targeted outcomes by customizing the process to their learning styles (watch videos, read articles, blogs, or interview specialists, etc.). For example, while learning the topic Communication at Sea students are guided to investigate the question "What is the best way to communicate at sea". Students surf different online and offline resources and decide on the way to introduce their findings. The process driven by an intellectually challenging open-ended question, is aimed to deepen students' knowledge of 
the topic, utilize their experience and develop critical thinking skills. To meet these needs, students are organized into small groups to collaborate and determine the most efficient way to communicate at sea, meanwhile mastering the language. Students are assigned to consider alternative solutions combined with their personal experience and experts' knowledge. To sum up their inquiry, students are encouraged to choose an appropriate task to perform on their findings and justify their decision (group or individual presentation, case analysis, survey, interview, dispute etc.). After the final task students are involved in the whole group discussion to assess the effectiveness of the strategies they used, determine the areas that need further improvement to fill professional and language knowledge gaps. Such continual language performance provides teacher with better understanding of students' needs and ability to adjust the learning environment accordingly.

Integrating digital content into the learning process opens new horizons to differentiate students' pace and path and, as a result, to improve their progress. In response to the present-day challenges, when teachers and students face a long-drawn-out lockdown, e-learning has become of a critical importance and sometimes the only way to deliver a learning content to students.

There are different ways to organize distance learning; generally, it can be differentiated into two methods - synchronous and asynchronous learning. Both of them have their benefits and drawbacks and can be used to provide personalized instruction.

Synchronous online learning means real time interaction between teacher and students by means of such online Zoom or Moodle conferences. From language teacher perspective, this method is applicable to organize live discussions to practice language, monitor students' progress and mentor learning procedure. From students' perspectives, online interaction provides them with an opportunity to exchange opinions, check their understanding of basic concepts, determine their gaps in knowledge and get immediate feedback.

Blended learning as an approach used to enhance students' involvement by combining class interaction with purposeful use of technology is an another essential tool to organize personalized instruction. Embedding the learning platform Moodle into the higher school education has reinforced learning and created additional opportunities to spread it beyond the classroom. Students are empowered to deeper learning through individual practice that occurs at any convenient time, pace and the level they require. Both quick learners and students who need more time for practicing benefit from the opportunity to glide through different tasks to gain knowledge, train targeted skills, reflect on their success, and do remedial work.

In spite of the fact that teacher may feel overloaded to search, adapt, differentiate, and upload various learning contents and tasks to be practiced, it eventually saves teacher's time and can be administrated without day-to-day instruction. Moreover, it provides various opportunities for controlled practice, selfassessment and reflection as well as an access to new learning content, video tutorials, and virtual libraries.

In addition, the teacher can analyze computerbased statistics concerning students' success and evaluate learning achievements and quality of different tasks. These data include information on the task validity (too difficult/easy), time students needed to complete the task, amount of attempts, and typical mistakes. These data are an integral part of training, used to provide remediation and additional practice to support students in their needs and reinforce learning with individual instruction (Barsuk, 2016). Regular data analysis is one of the core components of personalized instruction as it drives the entire learning process. Data reviewing can also provide students with opportunities to reflect on their efforts. Once identified, the learning goals as well as the criteria to assess language mastery are a subject of analysis for the students to take ownership for their learning. Monitoring their achievements against the learning goals students are encouraged to identify their strengths and weaknesses, set new goals, drive their own learning, and choose a proper way to demonstrate language mastering.

Targeted instruction is another basic component of personalization which means aligning students' needs to the established learning goals. For the teacher, it means bringing students up to the required skills mastery by choosing the adaptive content and scaffolding techniques for each student (Maile, Cooper, 2018).

Our practice reveals the possibility to divide or, more explicit to say, to unite students into three-four small groups around their interests, learning style, individual learning pace, and skills level. Naturally, the groups will not be of the same size as well as the basic need of the group members will be different. Teacher, though, will have to discuss the priority needs with the students either individually or by developing a questionnaire and encourage students to complete it. If a certain group of students has been taught for a semester or longer, the teacher is sure to know a lot about the students' preferences, likes and dislikes, skills level, and favourite approaches to learning. 
To start with targeted instruction, the teacher should be familiarized well with the institutionally approved communicative competencies to be mastered by students. Next to do is to recognize the differences between the cognitive levels presented by the action verbs in Bloom's taxonomy table (Huitt, 2011). Then, to formulate lesson objectives depending on what each group of students is able to do in their independent work. For example, at the lesson on the bridge team composition, the productive activities may be: compare the duties of the bridge team members (for advanced students), explain the duties of the bridge team members (for average level students), and define the duties of the bridge team members (for low level students).

At the English lessons of the PPP structure, teacher needs to organize the presentation and practice stages with controlled exercises for the whole group due to the purpose: to involve students into the English language atmosphere and familiarize them with the lesson objective and new language items. The stages where targeted instruction can become apparent are semi-controlled and freer practice, where teacher organizes learning stations with the necessary training aids available, including playlists. With the EASA lesson structure, the stages appropriate for fully displayed targeted instruction are the activate stages.

Targeted instruction requires some rules for a semester or an academic year to be discussed and agreed on between teacher and students. In most cases, those rules reveal the scope of personalized instruction teacher is apt to with a certain group of students. Implementing targeted instruction, teacher should also develop a set of personal rules to establish and follow: how to define the criteria for forming small groups, change the small groups composition in response to changing needs, work with individual students when necessary, conduct small groups instruction, organize the final productive activity bringing all the students together. Each of these issues is of profound importance at a communicative lesson of Maritime English. Without establishing them, a lesson can get chaotic with no delivery output from students.

What actually makes targeted instruction easier is the possibility for initial testing of the freshly enrolled students that can be done with the support of the institutional authorities. Homogeneous academic groups formed on the basis of their English language introductory level are an excellent platform for introducing targeted instruction which in such case is mostly focused on individual students' interests and learning pace.
Targeted instruction goes together with playlists, ingenious and, at the same time, simple as well as time-consuming tool for personalized instruction. Having appeared in the meaning of a list of songs to be played and listened to, the notion has swiftly penetrated into the world of video and audio, later capturing the world of teaching methodology. A playlist means a list of instructions, tasks, exercises, possible resources etc. for the whole group of students or for a few and even single students to follow in their independent out-of-class work. Using playlists in teaching Maritime English can serve well in cases when students of senior courses have their shipboard practice, when teachers implement IT technologies and novel teaching and learning strategies, but also when they teach students in a traditional way giving them regular home tasks. In our experience, they are especially efficient for distant students, who can clearly see their learning perspectives, apply their dominant learning styles and distribute the time between their work and studies. The current pandemic circumstances demonstrate how excellent the playlists are in instructing students and monitoring their progress.

Playlists can be presented in the form of a list or a table with the tasks for the next lesson, for a week, month, for a module or for the whole semester. For the students' convenience, they can be uploaded on learning platforms, in our case, Moodle, attached to emails, sent by Viber, Facebook, Telegram or any other social network. Personalized playlists can be used for instructing students for those with exceptionally low, intermediate, or advanced Maritime English skills. Their performance is assessed via Moodle or Zoom video conferences as oral communication skills are a major focus in teaching Maritime English.

A digital playlist format used by us consists of: informing students about the next week topic/s, listing the tasks they are supposed to do (sequenced activities and resources), providing instructions on grammar or vocabulary items, setting the number of points for the tasks and the date for formative assessment.

In case the students are in one group irrespective of their cognitive skills set, teacher organizes them in small groups based on their initial content test and develops a playlist within the objective of one lesson for each small group separately. The differences will concern the choice of exercises, tasks to the video (write an essay using the plan/answer the questions/mark the statements as True or False). The privilege for students is in learning the lesson at their own pace, order of doing the tasks, availability of different resources, possible assistance from peers or relatives etc. 
The use of playlists shifts the responsibility for their success in mastering Maritime English to the students themselves if the assessment system is approved and realized by them.

In their turn, the teachers should select the basic channels of communication, inform students about the number of points they can get for the tasks, develop and apply tests and quizzes, set approximate target timelines, appoint dates for formative assessment and more. To personalize, teacher should know and consider specific students' interests, needs and skills level.

Conclusions and suggestions. Personalized instruction is an efficient pedagogical approach to create new student-focused environment, to boost students' motivation and reinforce learning. It builds new relations between students and teacher, involving students into data making decision and taking ownership for their learning. To implement it into practice successfully, we have focused on its four components in teaching Maritime English: flexible content, digital tools, targeted instruction, and personalized playlists. Teacher drives the learning process by responding to students' needs, providing flexible learning content and tasks, and customizing learning to individuals. Teacher acts as a mentor, coach and facilitator through learning tools differentiation, collecting data on students' progress, providing targeted instruction and creating personalized playlists to adjust individuals' learning styles and contribute to the sustainable success of each student.

\section{BIBLIOGRAPHY}

1. Барсук С. Л. Computer-aided Tools to Assess Students' Professional Communicative Skills. Інформаиійні технологї в освіті. Херсон : ХДУ, 2016. Вип. 28. С. 94-105.

2. Кудрявцева В. Ф. Можливості реалізації глибинного навчання в курсі морської англійської мови. Педагогіка формування творчої особистості у вищій $і$ загальноосвітній школах. Запоріжжя : КПУ, 2019. Вип. 62. Т. 2. С. $240-244$.

3. Bautista Romiro G. The effects of personalized instruction on the academic achievement of students in physics. International Journal of Arts \& Sciences. 2012. P. 573-583. URL: http://universitypublications.net/ijas/0505/pdf/ULV212. pdf (Last accessed: 14.06.2020).

4. Huitt W. Bloom et al.'s taxonomy of the cognitive domain. Educational Psychology Interactive. Valdosta, GA : Valdosta State University, 2011. URL: http://www.edpsycinteractive.org/topics/cognition/bloom.html (Last accessed: 03.06.2020).

5. IMO Model Course 3.17 Maritime English. London, IMO, 2015. 297 p.

6. Johns Scott \& Wolking Mike. The Core Four of Personalized Learning: The Elements You Need to Succeed. Education Elements. 2015. URL: https://www.edelements.com/hubfs/Core_Four/Education_Elements_Core_Four_White_Paper.pdf (Last accessed: 10.05.2020).

7. Keefe James W., Jenkins John M. Personalized Instruction: Changing Classroom Practice. Eye On Education : Larchmont, NY, 2000. 239 p.

8. Kim Anthony. Personalized Learning: The Ultimate Guide. Education Elements. URL: https://tophat.com/blog/ personalized-learning-the-ultimate-guide/ (Last accessed: 06.05.2020).

9. Mesecar Doug. New Evidence That Personalized Learning Can Produce Powerful Results. Lexington institute online library. 2016. URL: https://www.lexingtoninstitute.org/new-evidence-personalized-learning-can-produce-powerful-results/ (Last accessed: 28.05.2020).

10. Maile Craig A., Cooper Margi Stone. The CIMC Guide to Developing Modules for Self-Paced Learning: A Handbook for Teachers. Oklahoma Department of Career and Technology Education. Stillwater, Oklahoma, 2018. 80 p.

11. Redding S. Personal competency: A framework for building students' capacity to learn. Philadelphia, PA : Temple University, Center on innovations in Learning, 2014. 40 p.

12. Slocum Natalie. What is Personalized Learning. Aurora Institute. 2016. URL: http://www.inacol.org/news/what-ispersonalized-learning/ (Last accessed: 28.06.2020).

13. Sota M. S. Co-designing instruction with students. Philadelphia, PA : Temple University, Center on Innovations in Learning, 2016. $71 \mathrm{p}$.

14. Vargo J. Six Examples of What Personalized Learning Looks Like. Education Elements. 2017. URL: https:// www.edelements.com/blog/six-examples-of-what-personalized (Last accessed: 18.06.2020).

15. Walkington Candace \& Bernacki Matthew L. Personalization of Instruction: Design Dimensions and Implications for Cognition. The Journal of Experimental Education. 2017. № 86 (1). URL: https://doi.org/10.1080/00220973.2017.1380590 (Last accessed: 05.05.2020).

16. Watanabe-Crockett Lee. Why personalized instruction can lead to powerful learning experiences. Solution Tree blog. 2017. URL: https://www.solutiontree.com/blog/personalized-learning-for-powerful-learning-experiences/ (Last accessed: 25.05.2020).

\section{REFERENCES}

1. Barsuk S.L. Computer-aided Tools to Assess Students' Professional Communicative Skills. Informatsiini tehnologii v osviti Ukrainy: stan, problemy, perspectyvy. Kherson: KSU, 2016. No. 28. pp. 94-105 [In English].

2. Kudryavtseva V. Mozhlyvosti realizatsii hlybynnoho navchannya v kursi morskoi angliyskoi movy [Opportunities for Deeper Learning Approach Implementation to Teach Maritime English]. Pedagogika formuvannya tvorchoi osobystosti u vyshchiy ta zagalnoosvitniy shkolah. Zaporizhzhia: CPU, 2019. No. 62. pp. 240-244 [In Ukrainian]. 
3. Bautista Romiro G. The effects of personalized instruction on the academic achievement of students in physics. International Journal of Arts \& Sciences. 2012. pp. 573-583. URL: http://universitypublications.net/ijas/0505/pdf/ULV212.pdf (Last accessed: 14.06.2020).

4. Huitt W. Bloom et al.'s taxonomy of the cognitive domain. Educational Psychology Interactive. Valdosta, GA: Valdosta State University. 2011. URL: http://www.edpsycinteractive.org/topics/cognition/bloom.html (Last accessed: 03.06.2020).

5. IMO Model Course 3.17 Maritime English. London, IMO. 2015. 297 p.

6. Johns Scott \& Wolking Mike. The Core Four of Personalized Learning: The Elements You Need to Succeed. Education Elements. 2015. URL: https://www.edelements.com/hubfs/Core_Four/Education_Elements_Core_Four_White_Paper. pdf (Last accessed: 10.05.2020).

7. Keefe James W. \& Jenkins John M. Personalized Instruction: Changing Classroom Practice. Eye On Education: Larchmont, NY, 2000. 239 p.

8. Kim Anthony. Personalized Learning: The Ultimate Guide. Education Elements. URL: https://tophat.com/blog/personalized-learning-the-ultimate-guide/ (Last accessed: 06.05.2020).

9. Mesecar Doug. New Evidence That Personalized Learning Can Produce Powerful Results. Lexington institute online library. 2016. URL: https://www.lexingtoninstitute.org/new-evidence-personalized-learning-can-produce-powerful-results/ (Last accessed: 28.05.2020).

10. Maile Craig A. \& Cooper Margi Stone. The CIMC Guide to Developing Modules for Self-Paced Learning: A Handbook for Teachers. Oklahoma Department of Career and Technology Education. Stillwater, Oklahoma. 2018.80 p.

11. Redding S. Personal competency: A framework for building students' capacity to learn. Philadelphia, PA: Temple University, Center on innovations in Learning, 2014. 40 p.

12. Slocum Natalie. What is Personalized Learning. Aurora Institute. 2016. URL: http://www.inacol.org/news/what-ispersonalized-learning/ (Last accessed: 28.06.2020).

13. Sota M. S. Co-designing instruction with students. Philadelphia, PA: Temple University, Center on Innovations in Learning. 2016. $71 \mathrm{p}$.

14. Vargo J. Six Examples of What Personalized Learning Looks Like. Education Elements. 2017. URL: https:// www.edelements.com/blog/six-examples-of-what-personalized (Last accessed: 18.06.2020).

15. Walkington Candace \& Bernacki Matthew L. Personalization of Instruction: Design Dimensions and Implications for Cognition. The Journal of Experimental Education. 2017. 86 (1). DOI: https://doi.org/10.1080/00220973.2017.1380590 (Last accessed: 05.05.2020).

16. Watanabe-Crockett Lee. Why personalized instruction can lead to powerful learning experiences. Solution Tree blog. 2017. URL: https://www.solutiontree.com/blog/personalized-learning-for-powerful-learning-experiences/ (Last accessed: 25.05.2020). 